\title{
Deformidade traqueal em equino
}

Leticia Garcia ${ }^{[a]}$, Alejandra Beatriz Britez Olmedo ${ }^{[b]}$, Raul Marcelo Maldonado Castillo ${ }^{[b]}$

\author{
[a] Universidade Federal do Paraná (UFPR), Curitiba, PR, Brasil \\ ${ }^{[b]}$ Hospital Equino Raul Maldonado, Mariano Roque Alonso, Paraguai
}

*Autor correspondente

e-mail: lezavdoskigarcia@gmail.com

\section{Resumo}

As alterações de formato da traqueia podem ser de origem congênita por malformação ou adquiridas. Raças de cavalos miniaturas e pôneis são propensas à malformação do desenvolvimento da traqueia, conhecida como scabbard trachea ou traqueia colapsada. Embora seja quase certamente uma anormalidade de desenvolvimento, geralmente é encontrada incidentalmente durante o exame endoscópico ou exame post mortem de pôneis maduros. Diferente de outras espécies, colapso traqueal primário em cavalos só foi relatado em cavalos maduros. 0 diagnóstico depende da endoscopia traqueal e da radiografia. Notase que a traqueia apresenta graus variáveis de compromisso luminal e anéis cartilaginosos danificados. A detecção precoce e criteriosa de problemas respiratórios é essencial para diagnóstico e tratamento efetivo. Foi recebido no Hospital Equino Raul Maldonado, animal da espécie equina, fêmea, 5 anos de idade, $390 \mathrm{Kg}$, raça Quarto de Milha, para tenoscopia da bainha digital. 0 procedimento foi realizado sob anestesia inalatória. Não houveram complicações transoperatórias. Aos 15 dias pós-cirúrgico, o animal passou a apresentar estertores respiratórios em momentos de estresse e esforço, não havendo histórico de problemas respiratórios anteriores conforme relato do proprietário. Procederam-se ao exame clínico, no qual a auscultação pulmonar e traqueal não apresentaram alterações. Verificaram-se presença de secreção nasal de coloração enegrecida e odor fétido em ambas as narinas. Procederam-se aos exames ultrassonográfico e radiográfico. A avaliação ultrassonográfica não revelou quaisquer alterações. 0 estudo do laudo radiográfico resultou em um achado de deformidade traqueal dorsoventral em porção cervical, caracterizada por um estreitamento interno com consequente diminuição de lúmen traqueal. 0 exame endoscópico revelou necrose, desprendimento de mucosa, presença de muco e tecido de granulação na traqueia em porção cervical. Foi coletado material para cultura por pinça através do canal de biopsia do 
endoscópio, sem resultados positivos para agentes infecciosos. 0 tratamento imediato incluiu o uso de dexametasona endovenosa a cada 24 horas para diminuir o grau de granulação, expectorante por via oral, acetilcisteina, e plasma rico em plaquetas foi depositado através do endoscópio com o objetivo de promover a regulação dos estágios da cicatrização tecidual. Houveram melhoras significativas quanto ao grau de estreitamento de lúmen traqueal. A terapêutica antimicrobiana incluiu uso de penicilina, metronidazol e gentamicina. Dado início o tratamento, a secreção nasal purulenta e de odor fétido desapareceu. Foram realizados exames endoscópicos a cada dois dias para debridamento de tecido necrótico. 0 animal nunca apresentou febre, porém, o tecido de granulação estava incontrolável. Dias após, passou a ser detectável estridor inspiratório e expiratório na auscultação traqueal. Um mês após a cirurgia, o animal apresentou episódio inédito de dispneia severa. Para estabilização do quadro clínico, procedeu-se a oxigenoterapia e traqueostomia emergencial. Porém, horas após a cirurgia, o animal, ainda em observação, entrou em quadro de falência respiratória anóxica e morreu em seguida. A necropsia revelou macroscopicamente redução de 75\% na área luminal e deformidade precoce em cartilagem traqueal. A pressão gerada pelo traqueotubo da anestesia na porção afetada foi responsável pela isquemia da mucosa traqueal. Suspeita- se que previamente à lesão, havia uma má-formação traqueal dorsoventral que permitiu a ocorrência desta injúria. A acumulação lenta e contínua de ácido carbônico exerce efeitos narcotizantes sobre o cérebro, fazendo com que os movimentos respiratórios se tornem cada vez mais débeis. A falência respiratória é o estágio terminal da insuficiência respiratória, na qual a atividade dos centros respiratórios diminui a um ponto tal que cessam os movimentos dos músculos respiratórios. Posteriormente, ocorre a paralisia de órgãos centrais por hipoxigenação e morte.

Palavras-chave: Trato respiratório superior. Traqueia. Colapso traqueal. 